KRZYSZTOF GOŁATA

\title{
SPOŁECZNA NIEODPOWIEDZIALNOŚĆ BIZNESU A NISZCZENIE WIZERUNKU PRZEDSIĘBIORSTWA
}

\section{WPROWADZENIE}

W debacie publicznej pojęcie „społeczna odpowiedzialność biznesu” zdecydowanie dominuje nad pojęciem „społeczna nieodpowiedzialność biznesu”. Przedsiębiorstwa, zgodnie z zasadami działań z zakresu public relations, public affairs czy komunikowania społecznego, koncentrują się na publikowaniu pozytywnych informacji o podejmowanych w tym zakresie działaniach. Wszelkie negatywne aspekty ich aktywności sa skrzętnie ukrywane (często stanowią tajemnice przedsiębiorstwa), gdyż nie budują one pozytywnego wizerunku ani pożądanej reputacji. Konsekwencje negatywnych informacji sa daleko idące. Jedno wydarzenie źle przyjęte przez opinię publiczną może przekreślić wiele lat pracy nad budowaniem pozytywnego wizerunku i dobrej reputacji. Należy bowiem pamiętać, że negatywne informacje i opinie zdecydowanie lepiej „sprzedają się” w mediach. Wydarzenia pozytywne są odbierane jako rzecz normalna i oczywista (np. fakt, że przedsiębiorstwo osiagnęło zaplanowany poziom zysku, zainteresuje niewielu), negatywne zaś informacje „żyją” o wiele dłużej w świadomości społecznej. O wycieku ropy naftowej czy wadach samochodu mówi się i pisze dłużej niż o najlepiej nawet przygotowanym i wydanym raporcie CSR.

Skoncentrowanie uwagi na wybranych aspektach problemu społecznej nieodpowiedzialności biznesu wynika z przyjętej przez autora hipotezy, że badania koncentrujące się wokół tego zagadnienia, a szczególnie jego przyczyn, mogą wpłynąć na większą identyfikacje problemu oraz zwiększyć efektywność społecznej odpowiedzialności firmy wobec jej interesariuszy. Praktyka wskazuje, że w ramach jednej firmy znajdujemy przykłady zarówno społecznej odpowiedzialności, jak i nieodpowiedzialności biznesu. Te drugie mają bardzo często jednostkowy wymiar ${ }^{1}$. W praktyce nie wydaje się możliwe całkowite wyeliminowanie negatywnych zjawisk towarzyszacych funkcjonowaniu przedsiębiorstwa. Uczynienie przedmiotem badań problematyki nieodpowiedzialnego biznesu pozwala: po pierwsze, na wyszczególnienie konsekwencji negatywnych reakcji; po drugie, na przeciwdziałaniu im w przyszłości. Dla każdego przedsiębiorstwa są to zagadnienia fundamentalne. Koncentracja publicznego

1 Przedsiębiorstwo realizuje zaplanowaną strategię CSR, ale w jej trakcie dochodzi do sytuacji, w której podejmowane są decyzje niemające nic wspólnego z odpowiedzialnym biznesem, a wręcz przeciwnie, opinia publiczna odbiera je jako przejaw społecznej nieodpowiedzialności. 
dyskursu na zagadnieniach CSR powoduje, że przedsiębiorstwa budują swój idealny obraz podmiotu gospodarczego działającego jedynie dla dobra publicznego. Dlatego też głównym celem artykułu jest odpowiedź na pytanie o źródła społecznej nieodpowiedzialności biznesu oraz wskazanie najbardziej spektakularnych przykładów tego zjawiska (dzięki m.in. działaniom mediów opinia publiczna dysponuje coraz większą liczbą negatywnych przykładów korporacji naruszających zasady odpowiedzialności społecznej). Ramy artykułu nie pozwalają niestety na szczegółowe omówienie wpływu CSI na wizerunek i reputację przedsiębiorstwa.

\section{SPOŁECZNA NIEODPOWIEDZIALNOŚĆ BIZNESU - ASPEKT TEORETYCZNY}

Przeciwnicy idei społecznej odpowiedzialności biznesu przekonuja, że obowiązkiem przedsiębiorstw jest maksymalizacja zysków i powiększanie wartości firmy, a nie udawanie, że „zamierzają uleczyć całe zło tego świata” ${ }^{2}$. Ich zdaniem państwo, a nie firmy powinno dbać o to, aby rynek funkcjonował prawidłowo. Można przyjąć, że takie podejście do roli przedsiębiorstwa stworzyło podwaliny do powstania pojęcia społecznej nieodpowiedzialności biznesu.

W literaturze anglosaskiej z pojęciem społecznej nieodpowiedzialności biznesu (corporate social irresponsibility - CSI) spotykamy się po raz pierwszy $\mathrm{w}$ latach siedemdziesiątych XX w. ${ }^{3}$ Społeczna nieodpowiedzialność biznesu identyfikowana jest z działaniami, które prowadzą do rozwoju firmy, ale odbywa się on kosztem całego systemu społecznego lub innego podmiotu gospodarczego; CSI związana jest także z naruszaniem prawa oraz zasad etycznych i moralnych. Firmy społecznie nieodpowiedzialne naruszaja prawa swoich interesariuszy, dopuszczając się m.in. oszustw i manipulacji, a ich szefowie podejmują decyzje, które stoją w sprzeczności z wyznawanymi przez nich wartościami. CSI sprowadza się także do ograniczania swojej aktywności tylko do płaszczyzny biznesowej, bez postrzegania społecznej roli przedsiębiorstwa w jego otoczeniu.

Społeczna nieodpowiedzialność biznesu jest często słusznie interpretowana jako przeciwieństwo społecznej odpowiedzialności biznesu. Powstaje zatem pytanie o źródła CSI. Mówiąc w sposób ogólny, można ich poszukiwać w relacjach między przedsiębiorstwem a jego interesariuszami, a także w istocie stosunków społecznych czy zasad funkcjonowania współczesnej gospodarki. Można wskazać szereg sytuacji, w których łatwiej mówić o przekraczaniu niż o zachowaniu kanonów społecznej odpowiedzialności biznesu. Firma narażona jest na zyskanie miana nieodpowiedzialnej z bardzo wielu powodów, a szczególnie gdy:

2 T. Clapham, Społeczna odpowiedzialność biznesu to ściema, „Nowa Konfederacja. Internetowy Miesięcznik Idei” 2(68), 2016, www.nowakonfederacja.pl/wp-content/uploads/2016/02/NK-68-Clapham-Sekowski.pdf.

${ }_{3}^{3}$ W. Leoński, Społeczna odpowiedzialność i nieodpowiedzialność biznesu, Studia i Prace Wydziału Nauk Ekonomicznych i Zarządzania, nr 39, t. 1, Wyd. US, Szczecin 2015. 
- osiagnięcie przez nią finansowego zysku jest często jedynym celem działania prezesa i zarządu firmy;

- ekonomiczny cel przedsiębiorstwa (zysk) jest ważniejszy niż społeczne koszty realizacji tego celu;

- pracownicy traktowani sa przedmiotowo i wykorzystywani, a nie traktowani, przez szeroko rozumiane kierownictwo przedsiębiorstwa, jako dobro wspólne;

- przedsiębiorstwo wykorzystuje pracę dzieci oraz więźniów, płaci poniżej ustawowego $\mathrm{w}$ danym państwie minimalnego wynagrodzenia, nie przestrzega zasad bezpieczeństwa pracy, nie przestrzega prawa do zrzeszania się;

- wszelkie istotne zmiany w funkcjonowaniu przedsiębiorstwa są narzucane arbitralnie, a nie przyjmowane w drodze konsensusu w dialogu z pracownikami;

- koszty ochrony środowiska nie sa istotne dla firmy, a jego degradacja jest tolerowana przez politycznych decydentów lub akceptowana przez opinię publiczna;

- decyzje (np. inwestycyjne) zarządu nie są przedmiotem konsultacji z społecznością lokalna, mimo że skutki działań firmy dotyczą jej społecznego otoczenia;

- zarząd wymusza na rządzących korzystne dla firmy decyzje, uciekając się do szantażu lub gróźb, np. finansowych;

- skutki nowych rozwiązań technologicznych nie są w pełni zweryfikowane lub sprawdzane w niewłaściwych warunkach i niejasnych procedurach;

- reklama i techniki marketingowe (np. niezrozumiały dla odbiorców język komunikatu marketingowego) dominują nad rzetelna informacją o cechach produktów lub świadczonych usługach;

- partnerzy biznesowi (banki, dostawcy, sprzedawcy) nie są traktowani w sposób uczciwy zgodny z zasadami społecznymi;

- manipulacja i oszustwa są stałym elementem funkcjonowania zarządu przedsiębiorstwa i dominują w komunikowaniu społecznym z interesariuszami;

- prawo traktowane jest instrumentalnie i interpretowane wyłącznie na korzyść przedsiębiorstwa i realizacji jego głównego celu;

- funkcjonowanie przedsiębiorstwa nie jest analizowane przez pryzmat norm etycznych i moralnych, ale oceniane wyłącznie przez pryzmat kategorii prawnych i finansowych;

- przedsiębiorstwo (zarząd) zamierza ukryć (i ukrywa) przyczyny negatywnych zjawisk i szuka odpowiedzialnych poza strukturami firmy;

- raporty oraz konkursy poświęcone raportom CSR bardzo często nie sa weryfikowane przez niezależne, wiarygodne instytucje powołane do tego typu audytów.

Zaproponowane powyżej źródła społecznej nieodpowiedzialności biznesu nie mogą uchodzić za kompletne. Sytuacje biznesowe nie zawsze dają się usystematyzować, gdyż bardzo często nie są one powtarzalne, a wpływ na nie ma wiele nieprzewidywanych czynników ${ }^{4}$.

${ }^{4}$ Trzeba w tym miejscu w pełni zgodzić się z poglądem, że przedsiębiorstwo niedbające o swój interes nie może uchodzić za społecznie odpowiedzialne. Zarządzający lekceważący podstawowe 
Niektórzy autorzy podkreślaja że społeczna odpowiedzialność biznesu wymaga kontroli, gdyż jej brak prowadzi do wypaczeń, czyli społecznej nieodpowiedzialności biznesu. Przemysław Wewiór stawia tezę, że jeżeli chcemy, aby biznes był społecznie odpowiedzialny, ,[...] to musimy sprawić, by się on opłacał. Oznacza to poszukiwanie środków nagradzania i karania za pozafi-

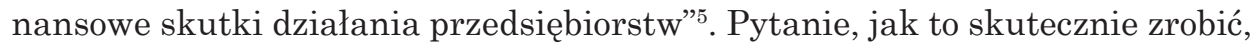
jest nadal aktualne.

\section{PLASZCZYZNY SPOŁECZNEJ NIEODPOWIEDZIALNOŚCI FIRM}

Nawet pobieżna analiza upublicznionych przypadków społecznej nieodpowiedzialności biznesu wskazuje, że niezależnie od wielkości przedsiębiorstwa dochodzi przede wszystkim do łamania zasad uczciwości wobec klientów oraz partnerów biznesowych, poszanowania praw pracowniczych oraz ochrony środowiska. Skala naruszeń zasad CSR jest duża, dlatego też autorzy (Fundacja CentrumCSR.pl) raportu „Społeczna odpowiedzialność biznesu w polskich realiach. Teoria a praktyka" dochodzą do wniosku, że obserwujemy duże zniechęcenie i rozczarowanie koncepcją CSR. „Dotychczasowy sposób propagowania tego zjawiska i jego skrajna komercjalizacja spowodowały, że zaufanie innych grup (niż korporacje) do CSR praktycznie nie istnieje"6. W efekcie obserwujemy dużą rozbieżność między teorią a praktyka, czyli między tym, co firmy mówią o działaniach CSR, a co rzeczywiście robią w tym zakresie.

Tym samym raport zwraca uwagę na dwa aspekty problemu. Po pierwsze, zakres działań w ramach CSR, a po drugie, sposób informowania opinii publicznej przez przedsiębiorstwo o realizowanych - w ramach CSR - przedsięwzięciach.

Należy również zauważyć, że firmy często rozszerzają zakres pojęcia społecznej odpowiedzialności biznesu, włączając w jego zakres działalność charytatywną (filantropię i dobroczynność) oraz klasyczny sponsoring.

Grzegorz Piskalski, komentując wyniki raportu na temat społecznej odpowiedzialności biznesu, potwierdza powyższe opinie i stwierdza, że istnieje duży rozdźwięk między deklaracjami firm a rzeczywistością?. Prawdziwy obraz rysuje się wówczas, gdy dochodzi do konfrontacji opinii właścicieli lub

zasady ekonomii i doprowadzający firmę do upadku tym samym nie realizują najważniejszego obowiązku społecznego - zapewnienia ludziom pracy i finansowych podstaw egzystencji. Bankructwo firmy oznacza szereg negatywnych skutków dla jej interesariuszy, np. wzrost bezrobocia, upadek kooperantów, problemy finansowe innych podmiotów gospodarczych.

${ }^{5} \mathrm{P}$. Wewiór, Obiecywali jak nigdy, nie dotrzymali słowa jak zawsze, czyli społeczna odpowiedzialność biznesu po polsku, www.nowyobywatel.pl/2012/10/12/obiecywali-jak-nigdy-nie-dotrzymali-slowa-jak-zawsze-czyli-spoleczna-odpowiedzialnosc-biznesu-po-polsku/.

${ }^{6}$ Społeczna odpowiedzialność biznesu w polskich realiach. Teoria i Praktyka, Raport z monitoringu społecznej odpowiedzialności największych polskich firm, Fundacja CentrumCST.PL, Warszawa 2015 (dalej jako: Społeczna odpowiedzialność biznesu).

${ }^{7}$ G. Piskalski, Biznes nieodpowiedzialny spotecznie, 2015, www.wiadomosci.ngo.pl/wiadomosci/1909294.html. 
zarządów firm z opiniami pracowników, związków zawodowych, mediów czy lokalnych społeczności. Firmy bardzo często nagłaśniają drobne inicjatywy w zakresie CSR, uciekając od fundamentalnych problemów. „W Polsce można nie płacić podatków i łamać prawa pracownicze, a równocześnie otrzymywać dyplom za społeczną odpowiedzialność i korporacyjną filantropię", konkluduje autor raportu, który jest efektem badań przeprowadzonych w 227 najważniejszych przedsiębiorstwach działajacych w Polsce ${ }^{8}$.

Dobrym przykładem społecznej nieodpowiedzialności biznesu w ramach relacji: firma-klient są losy tzw. frankowiczów. Kilka lat temu banki intensywnie namawiały klientów do zaciagania kredytów hipotecznych w frankach szwajcarskich, kusząc niższymi ratami spłat oraz dużą stabilnością tej waluty na rynkach światowych. Agresywna reklama nie mówiła nic na temat ryzyka związanego z zaciaganie kredytu w walucie, w której nie otrzymuje się np. wynagrodzenia. Nie informowano także o tym, że całkowite ryzyko takiej transakcji ponosi kredytobiorca. Banki bardzo często wprowadzały w błąd klientów, nie informując ich o wielu uwarunkowaniach towarzyszacym takim kredytom (lub informujacc tzw. małym drukiem). Dodatkowo język umów był tak zawiły (naszpikowany prawniczymi sformułowaniami), że większość klientów nie wiedziała do końca, co podpisuje. Nie trzeba dodawać, że kredyty frankowe były bardzo dobrym interesem dla banku (udzielano ich w złotych i tylko przeliczano na franki).

W pewnym momencie w wyniku decyzji szwajcarskiego banku centralnego wartość waluty w stosunku do złotego uległa znaczącej zmianie, a tym samym raty spłacane przez polskich kredytobiorców gwałtownie wzrosły. Banki nie wykazywały jednak zainteresowania losem swoich klientów, nie były one skłonne do podjęcia z nimi żadnych negocjacji, unikały wręcz kontaktów. W swoich oświadczeniach ich przedstawiciele ograniczali się jedynie do dość cynicznych stwierdzeń, że „biorący kredyty są dorosłymi ludźmi, bioracymi odpowiedzialność za swoje decyzje"9. Z czasem ton tych wypowiedzi łagodniał, ale do rozwiąania problemu jest jeszcze bardzo daleko. Żaden bank nie przystapił do negocjacji przed sądem polubownym. Grupa tzw. frankowiczów jest bardzo liczna, gdyż w skali kraju zawarto ponad 500 tys. tego typu umów ${ }^{10}$. Mimo że wiele banków ma własne kodeksy etyczne, którymi bardzo często się chwali, wystawiaja przeciw frankowiczom armię doskonale wykształconych i opłacanych prawników.

Spektakularnym przykładem społecznej nieodpowiedzialności biznesu „na odległość” jest przypadek polskiej firmy LPP. W 2013 r. w Bangladeszu zawaliła się fabryka odzieżowa Rana Plaza. W katastrofie zginęło ponad tysiąc pracowników. W Internecie pojawiło się zdjęcie metki jednej z marek LPP. Reakcja firmy na ujawnienie tego faktu była dość zaskakujacca. Zarząd w wydanym oświadczeniu stwierdził, że szycie odzieży jest zlecane - przez pośredników - niezależnym producentom i firma nie wie (więc też nie może ponosić odpowiedzialności za to), gdzie i w jakich warunkach powstaja jej produkty. Ponad

\footnotetext{
8 Społeczna odpowiedzialność biznesu, s. 10.

9 Ibidem, s. 55-58.

10 Ibidem, s. 57.
} 
70 firm korzystających z usług fabryki Rana Plaza stosunkowo szybko porozumiało się i podpisało porozumienie o wypłacie odszkodowań i zwiększeniu wydatków na poprawę bezpieczeństwa pracowników. LPP długo „analizowało sytuację" i dopiero po kilku miesiącach, pod groźbą bojkotu swoich sklepów w Polsce, przystapiło do porozumienia ${ }^{11}$.

Najwięcej problemów z poszanowaniem przyjętych reguł w zakresie ochrony środowiska maja koncerny petrochemiczne. Nieodpowiedzialność polega na świadomym łamaniu zasad bezpieczeństwa lub braku kontroli nad przebiegiem procesów technologicznych. W rezultacie dochodzi do wielu katastrof ekologicznych, a w najtragiczniejszych przypadkach - śmierci pracowników lub osób mieszkających np. w pobliżu rafinerii lub pól naftowych.

Najbardziej spektakularnym przykładem społecznej nieodpowiedzialności biznesu w sektorze petrochemicznym był wybuch na zlokalizowanej w Zatoce Meksykańskiej platformie wiertniczej Deepwater Horizont należącej do British Petroleum (BP). W kwietniu 2010 r. doszło do wybuchu, w wyniku którego śmierć poniosło jedenastu pracowników BP, a do połowy lipca do wód zatoki przedostawało się 25 tys. baryłek ropy naftowej dziennie. Jedną z przyczyn katastrofy były nadmierne oszczędności w wydatkach na budowę systemów bezpieczeństwa ${ }^{12}$. Szefowie BP bagatelizowali skutki katastrofy i przez długi czas nie chcieli uznać swojej odpowiedzialności za doprowadzenie do niej oraz nieudolnie prowadzoną akcję ratunkowa. Próbowano także ukryć niewygodne dla koncernu fakty, obarczając odpowiedzialnością inną firmę. Dopiero naciski światowej opinii publicznej zmusiły koncern do zwiększenia nakładów na zatrzymanie wycieku ropy i usuwanie skutków katastrofy ekologicznej.

$\mathrm{O}$ fałszowanie danych dotyczacych wycieku ropy oskarżany był holendersko-brytyjski Shell. Amnesty International i Friends of the Earth International twierdziły, że koncern złamał standardy odpowiedzialnego biznesu opracowane przez OECD, wprowadzając w przestrzeń publiczną fałszywe informacje o przyczynach wycieków ropy naftowej z rurociagów w Nigerii. Shell próbował przekonać międzynarodową opinię publiczna, że przyczyną większości wycieków były akcje sabotażu, szczególnie w delcie Nigru. W takiej sytuacji mieszkańcom - zgodnie z miejscowym prawem - nie należały się żadne odszkodowania za zniszczone środowisko ${ }^{13}$. Międzynarodowe naciski, nie tylko organizacji proekologicznych, zmusiły władze koncernu do zweryfikowania swoich danych i wypłacenia odszkodowań.

Problemy z ochroną środowiska mają także koncerny motoryzacyjne, czego najlepszym dowodem była afera $\mathrm{z}$ fałszowaniem oprogramowania przez koncern Volkswagena. W 2015 r. amerykańska federalna Agencja Ochrony Środowiska (EPA) postawiła niemieckiemu koncernowi zarzut instalowania $\mathrm{w}$ samochodach z silnikiem diesla oprogramowania ograniczającego wielkość emisji tlenków azotu w trakcie badań testowych. Działania koncernu miały

\footnotetext{
11 Ibidem, s. 70

12 A. Staliński, Bojkot BP za wyciek ropy w Zatoce Meksykańskiej-studium przypadku, 2014, www.newpr.pl/bojkot-bp-za-wyciek-ropy-w-zatoce-meksykanskiej-studium-przypadku.

13 Shell oskarżony o fałszowanie danych o wyciekach ropy w Nigerii, 2011, http://ulicaekologiczna.pl/technologie/shell-oskarzony-o-falszowanie-danych-o-wyciekach-ropy-w-nigerii.
} 
na celu przekonanie opinii publicznej, że VW jest jednym z najbardziej proekologicznych producentów samochodów na świecie, a ponieważ ekologia jest modna (szczególnie w USA), chodziło także o zwiększenie sprzedaży, a więc zysków koncernu.

Volkswagen przyznał się do fałszerstwa, a tym samych do jednego z największych oszustw w historii motoryzacji ${ }^{14}$. W rozesłanej do mediów informacji prasowej podano, że takie oprogramowanie zamontowano w 800 tys. samochodów zakupionych w USA. Straty finansowe VW liczone są w miliardach dolarów (euro), całkowite zaś straty wizerunkowe trudne są do oszacowania. „Afera spalinowa, zwana czasem także »dieselgate«, okazała się najpoważniejszym kryzysem w liczącej 78 lat historii firmy Volkswagen, a jej skutków nie da się jeszcze przewidzieć" ${ }^{15}$. Warto również nadmienić, że w mediach natychmiast pojawiły się wątpliwości i pytania, czy koncern Volkswagena były jedynym motoryzacyjnym gigantem stosujacym podobne praktyki. Szybko okazało się, że miał on kilku następców.

\section{RANKINGI SPOŁECZNEJ NIEODPOWIEDZIALNOŚCI BIZNESU}

W 2005 r. szwajcarski oddział Greenpeace zorganizował po raz pierwszy konkurs: Public Eye Award, w którym wskazał najbardziej społecznie nieodpowiedzialne przedsiębiorstwa. W celu spopularyzowania przedsięwzięcia jego wyniki były dotychczas ogłaszane w trakcie corocznego, największego spotkania polityki i biznesu, czyli Światowego Forum Ekonomicznego w Davos. Wyróżnione (przez jurorów i powszechne głosowanie) firmy zostały oskarżone o korupcję, dewastację środowiska, brak szacunku dla pracowników i ich wyzysk, namawianie do niepłacenia podatków. Od 2005 r. działacze Greenpeace wyróżnili m.in. Chevron, Gazprom, GAP, Shell, Goldman Sachs, Barclays, Vale, Samsung, Neste Oil, Roche, Bridgestone, Novartis, Citigroup, Walt Disney, Wal-Mart.

Warto w tym momencie zauważyć, że w ramach Public Eye Award nie oceniano kompleksowych działań poszczególnych koncernów, a jurorzy i opinia publiczna skupiali się tylko na jednym aspekcie lub regionie funkcjonowania firm ${ }^{16}$. Na przykład wskazano na Chevron Corporation i niszczenie przez firmę środowiska w Boliwii, a Citigroup „nagrodzono” za doradzanie firmom, jak uniknąć płacenia podatków, Walt Disney zaś został „wyróżniony” za produkowanie zabawek w Chinach i nieujawnianie miejsca ich produkcji (podejrzenie o wykorzystywanie darmowej pracy więźniów). W ten sposób działacze Greenpeace podkreślali, że każde przekroczenie obowiązujących norm i zasad

\footnotetext{
${ }_{14}$ Ubocznym efektem tej afery było pojawiające się w mediach pytanie: czy zarzut fałszowania badań samochodów można postawić tylko Volkswagenowi? Kilka firm przyznało się, że robiło to, ale na mniejszą skalę.

15 Volkswagen ujawnia szczegóty planu uporania się ze skutkami afery spalinowej, 2015, www.biznes.pl/volkswagen-ujawnia-szczegoly-planu-uporania-sie-ze-skutkami-afery-spolinowej.

16 Public Eye Award, 2016, www.publiceye.ch/en/campaigns/public-eye-awards.
} 
pociaga za sobą straty wizerunkowe oraz wpływa negatywnie na reputację koncernu, ponoszącego odpowiedzialność za wszelkie swoje działanie niezależnie od miejsca na świecie.

Od kilku lat internauci układaja listę „Najbardziej znienawidzonych firm w USA”, która publikuje portal www.24/7wallst. Podobnie jak w przypadku omówionej powyżej „nagrody”, internauci wskazują firmy działające na rynku amerykańskim (także firmy zagraniczne), które w minionym roku (ranking publikowany jest w styczniu) jednym z przedsięwzięć zasłużyły sobie na miano „najgorszej”. Większość firm, które trafiły na listę, wykazało się społeczną nieodpowiedzialnościa, naruszając prawa pracowników, oszukując klientów lub niszcząc środowisko. Pierwotnie lista składała się z dwunastu firm ułożonych w kolejności alfabetycznej, obecnie zaś w rankingu notowanych jest dziesięć przedsiębiorstw i nie ma już układu alfabetycznego. W poszczególnych latach na listach można było spotkać światowych gigantów (np. Toyota i BP), jak i firmy szerzej nieznane europejskim klientom (np. Dish Network czy Spirit Airlines).

Duże międzynarodowe koncerny zostały skrytykowane i „ukarane” za działania, które można zaliczyć do społecznie nieodpowiedzialnego biznesu. Na przykład w 2014 r. w zestawieniu znalazły się McDonald's oraz Wal-Mart za politykę niskich płac dla pracowników. W tym samym roku internauci krytycznie ocenili Ubera, któremu zarzucono nieuczciwą konkurencję i możliwość inwigilacji klientów. Cztery lata wcześniej na liście znalazła się Toyota (za ponadczterotygodniowe opóźnienie w przeproszeniu amerykańskich konsumentów za podejrzane wypadki samochodów tej marki) oraz dwa banki: Citgroup oraz Bank of America (za pazerność we wzroście opłat za korzystanie z bankomatów ${ }^{17}$ ).

Liderem opublikowanej w styczniu 2017 r. listy ${ }^{18}$ została firma Comcast, która jest największym operatorem telewizji kablowej i dostawcą usług internetowych w Stanach Zjednoczonych. Oszukiwała ona abonentów, doliczając do rachunków dodatkowe opłaty za sprzęt niezamawiany przez klienta.

Źródłem informacji o negatywnych praktykach biznesowych jest - powstały w 1994 r. - American Customer Satisfaction Index (ACSI), niezależny wskaźnik satysfakcji konsumentów w Stanach Zjednoczonych ${ }^{19}$. Metodologia ACSI oparta jest na badaniu takich zmiennych, jak: oczekiwania klienta, jakość i postrzegana wartość produktów i usług, satysfakcja i lojalność klienta wobec firmy, treść skarg i reklamacji. Analizując wskaźnik ACSI przez pryzmat społecznej nieodpowiedzialności biznesu, należy stwierdzić, że obrazuje on relacje: firma-klient.

W'śód wielu negatywnych przykładów nieodpowiedzialnego biznesu odnotowanych w 2016 r. przez ACSI wskazać można na działania pracowników

\footnotetext{
17 Opłata za korzystanie z bankomatu wzrosła o 5 USD; klienci pamiętali o gigantycznych kwotach pochodzących od amerykańskich podatników, a przeznaczonych na ratowanie banków przed upadkiem.

${ }_{18} \mathrm{Na}$ liście ponownie jest 12 firm.

19 American Customer Satisfaction Index 2016, www.theacsi.org/news-and-resources/customer-satisfaction-reports/reports-2016.
} 
Wells Fargo Bank, którzy przez trzy lata otwierali nowe konta „starym” klientom, ale bez ich wiedzy. Pracownicy banku otrzymywali premię, która była uzależniona od liczby nowych rachunków. Kierownictwo banku przekonywało, że nic nie wiedziało o takich praktykach swoich pracowników.

Analiza rankingów publikowanych w poszczególnych lata pozwala zauważyć, że nazwy firm powtarzają się. Oznacza to, że społecznie nieodpowiedzialne przedsiębiorstwa nie przywiązuja znaczenia do krytyki, jaka je spotyka (rankingi komentowane są przez media) lub nic nie robia, aby poprawić swój wizerunek oraz reputację w oczach opinii publicznej. Głębsza analiza tego problemu wykracza jednak poza ramy tego opracowania.

\section{WNIOSKI}

Społeczna nieodpowiedzialność biznesu nie może przesłonić znaczenia oraz wagi CSR w gospodarce. Społeczna odpowiedzialność biznesu oceniana jest obecnie przez pryzmat praktycznych działań firm, a nie teoretycznych założeń CSR. Jednak koncentrowanie swoje uwagi tylko na pozytywnych stronach wypacza problem. Można założyć, że naświetlanie i eliminowanie przypadków społecznej nieodpowiedzialności biznesu przyczynia się do wzrostu efektywności społecznej odpowiedzialności biznesu.

Należy pamiętać, że dobrymi przykładami działań CSR chwalą się wszystkie firmy, o wpadkach zaś nikt nie chce mówić i stara się je skrzętnie ukryć przed opinią publiczna. O dobrych praktykach dowiadujemy się natychmiast (raport roczny), o złych zaś zostaniemy poinformowani np. przez media po pewnym czasie.

Dlatego też potrzebny jest uniwersalny mechanizm weryfikowania dobrych praktyk, które często przyjmujemy w dobrej wierze. Oskarżenie np. przez media o społeczną nieodpowiedzialność biznesu obciążone jest ryzykiem wszczęcia postępowania sądowego przez przedsiębiorstwo oskarżane o praktyki niezgodne z duchem CSR. Firmy, wspierane przez rzesze prawników, wytaczają procesy, oskarżając np. media o straty wizerunkowe poniesione w wyniku „pomówienia” o społeczną nieodpowiedzialność. Nie trzeba dodawać, że ewentualne odszkodowania warte są miliony dolarów, a procesy często długotrwałe.

Istnieją tzw. trudne branże, w których bardzo często może dochodzić i dochodzi do naruszeń zasad CSR, np. ochrony środowiska (petrochemia, motoryzacja), praw pracowniczych (przemysł odzieżowy), praw konsumentów (przemysł farmaceutyczny).

Klienci na ogół nie wierzą w przekaz producentów np. o poziomie spalania paliwa przez samochody. Fabryczne pomiary przeprowadzane sa w nierealnych - dla przeciętnego kierowcy - warunkach eksploatacji pojazdu. Jest to trochę „sztuka dla sztuki”: my (producenci) piszemy o tym, gdyż takie sa wymogi, ale klienci i tak nie dają wiary tym zapisom (wiedza, że takie zapisy sa wymagane, ale sa absolutnie nieweryfikowalne).

Współczesne firmy stają przed dylematem, jak oszacować (nie tylko w aspekcie finansowym) wartość skutków swojej społecznej nieodpowiedzial- 
ności. Jakie działania, w jakim okresie i z jaką intensywnością muszą podjąć (np. Volkswagen), aby zrekompensować skutki spowodowane fałszowaniem pomiaru emisji spalin. Można spotkać się z opiniami, że firma przed długi czas będzie kojarzyła się z tą aferą i nieważne, ile pozytywnych rzeczy zrobi. Społeczna nieodpowiedzialność biznesu nie może być identyfikowana ze stratami finansowymi przedsiębiorstwa.

Należy także pamiętać, że wykrycie nieprawidłowości w jednej firmie rodzi medialne pytania o zachowanie innych podmiotów tej samej branży (czy tylko VW manipulował oprogramowaniem, czy tylko pracownicy Biedronki mieli problemy z pracodawcą itp.).

dr Krzysztof Gołata

Uniwersytet Ekonomiczny w Poznaniu

krzysztof.golata@ue.poznan.pl

\section{CORPORATE SOCIAL IRRESPONSIBILITY AND DESTRUCTION OF THE CORPORATE IMAGE}

\section{Sum mary}

The concept of corporate social irresponsibility appears relatively rarely in literature and public discourse. Companies are more likely to inform about positive aspects of their non-profit activities (for their employees, local communities, the environment) than about issues that worsen their image and reputation. However, talking about negative aspects of non-commercial activities seems important and worthwhile as it eliminates pathologies (in terms of corporate social irresponsibility) and increases social trust in activities related to corporate social responsibility. 